\title{
"PERLINDUNGAN HUKUM DALAM PEMULIHAN ASET BAGI KORBAN TINDAK PIDANA PENCUCIAN UANG YANG TERCAMPUR DENGAN ASET PELAKU"
}

\author{
Satriawan Sulaksono \\ Email : satriawansulaksono@gmail.com \\ Kejaksaan Negeri Surakarta \\ Widodo Tresno Novianto \\ Email:novianto@consultant.com \\ Supanto \\ Email: supanto8787@gmail.com \\ Dosen Fakultas Hukum Universitas Sebelas Maret Surakarta
}

\begin{abstract}
This article aims to determine the importance of legal protection in the recovery of assets for victims of money laundering whose assets have been mixed with the assets of the perpetrators to be returned to the victims of the crime. This research is a type of normative / doctrinal research using legislation approach and conceptual approach. The problem of this research is the lack of legal norms in Law Number 8 Year 2010 on Prevention and Eradication of Money Laundering Crime so that the recovery of crime victims' assets can not be fulfilled maximally, although the explanation of the law aims to trace assets and return to the victims. The results of this study indicate that the victim of money laundering crime must take another mechanism in the form of a lawsuit to obtain compensation from the perpetrator, this is different if the predicate offence is corruption, then the assets of the perpetrator can be confiscated and burdened with replacement money. Therefore it is necessary to revise the Law on Prevention and Eradication of Money Laundering Crime
\end{abstract}

Keyboard: Money laundring; Asset Recovery; victim; legal protection

\begin{abstract}
Abstrak
Artikel ini bertujuan untuk mengetahui pentingnya perlindungan hukum dalam pemulihan aset bagi korban tindak pidana pencucian uang yang asetnya telah tercampur dengan aset pelaku agar dapat dikembalikan kepada korban tindak pidana tersebut. Penelitian ini merupakan jenis penelitian normatif/doktrinal yang menggunakan metode pendekatan perundang-undangan dan pendekatan konseptual. Permasalahan dari penelitian ini adalah adanya kekurangan norma hukum pada Undang-Undang Nomor 8 Tahun 2010 tentang Pencegahan dan Pemberantasan Tindak Pidana Pencucian Uang sehingga pemulihan aset korban tindak pidana belum dapat dipenuhi secacara maksimal, meskipun penjelasan undang-undang tersebut bertujuan menelusuri aset dan mengembalikan kepada korban. Hasil penelitian ini menunjukan bahwa korban tindak pidana pencucian uang harus menempuh mekanisme lain berupa gugatan ganti kerugian untuk mendapatkan ganti kerugian dari pelaku, hal ini berbeda jika tindak pidana asal adalah korupsi, maka aset pelaku dapat disita dan dibebani uang pengganti. Oleh karena itu perlu adanya revisi Undang-Undang Pencegahan dan Pemberantasan Tindak Pidana Pencucian Uang.
\end{abstract}

Keyword: Pencucian Uang; pemulihan aset; korban; perlindungan hukum 


\section{A. Pendahuluan}

Dalam Undang-Undang Dasar Negara Republik Indonesia Tahun 1945 telah ditegaskan dengan jelas bahwa Negara Indonesia berdasarkan atas hukum, tidak berdasarkan atas kekuasaan belaka. Bahkan dalam Amandemen ketiga Undang-Undang Dasar Negara Republik Indonesia Tahun 1945 dalam Pasal 1 ayat (3) yang dinyatakan bahwa "Negara Indonesia adalah negara hukum". Hukum menetapkan apa yang harus dilakukan dan atau apa yang boleh serta yang dilarang. Sasaran hukum yang hendak dituju bukan saja orang yang nyata-nyata berbuat melawan hukum, melainkan juga perbuatan hukum yang mungkin akan terjadi, dan kepada alat perlengkapan negara untuk bertindak menurut hukum. Sistem bekerjanya hukum yang demikian itu merupakan salah satu bentuk penegakkan hukum. (Evi Hartanti, 2007:1).

Tindak Pidana Pencucian Uang (Money Loundry) sebagaimana diatur dalam UndangUndang Nomor 8 Tahun 2010 tentang Pencegahan dan Pemberantasan Tindak Pidana Pencucian Uang sesungguhnya bukan sekedar kriminalisasi, namun dengan perangkat yang ada didalam undang-undang tersebut baik substansi hukum dan struktur hukum pencukung antara lain PPATK (Pusat Pelaporan dan Analisis Transaksi Keuangan) seyogyanya juga sudah dapat digunakan untuk mengikuti aliran uang hasil kejahatan (follow the money termasuk aset korban kejahatan oleh pelaku yang telah dialihkan. Sebab jika pemberantasan tindak pidana pencucian uang hanya mengedepankan untuk memidana pelaku tanpa memulihakan aset korban yang mengalami kerugian, maka penegakan hukum akan semakin jauh dari hakekat tujuan keadilan terlebih bagi korban tindak pidana sehingga menelusuri kemana aliran uang (asset tracing) dengan tujuan untuk memulihkannya kepada korban yang telah dirugikan secara ekonomi tersebut.

Sampai saat ini, dimanapun terjadinya pencucian uang ada dua cara modern dan cara tradisional. Walaupun dikatakan bahwa tidak ada dua sistem pencucian uang yang sama, namun pada umumnya proses pencucian uang modern terdiri dari tiga tahap, yaitu placement, layering dan integration (Yenti Ganarsih, 2016:22).

Dalam hal hasil kejahatan masih utuh tersimpan pada tahap placement dan setelah ditelusuri diketahui secara pasti uang/aset yang tersimpan tersebut adalah hasil kejatahatan, maka penyelesaian pengembaliannya cenderung mudah yaitu uang/aset tersebut dikembalikan kepada korban melalui putusan pengadilan yang berkekuatan hukum tetap yang dilaksanakan oleh Jaksa selaku pejabat yang berwenang melakukan pelaksanaan putusan pengadilan (execution). Apabila tahapan pencucian uang tersebut sudah sampai pada tahap Integration maka sudah sangat sulit untuk memisahkan dan membedakan mana aset hasil kejatahan dan mana aset sah dari pelaku tindak pidana itu sendiri. Sebagai suatu contoh, pelaku kejahatan penggelapan senilai Rp. 1.000.000.000,- (satu milyar rupiah) telah melakukan pencucian uang yang telah sampai tahap integration dimana uang tersebut disatukan dengan uang sah untuk membeli properti senilai Rp. 10.000.000.000,- (sepuluh milyar rupiah), dengan catatan Rp. 9.000.000.000,- (sembilan milyar rupiah) adalah uang sah pelaku tersebut. Tidaklah mungkin seluruh properti tersebut akan dikembalikan atau diserahkan kepada korban, sebab kerugian korban hanyalah Rp. 1.000.000.000,- (satu milyar rupiah).

Berdasarkan hal tersebut, maka artikel ini akan membahas tentang pemulihan aset korban dalam tindak pidana pencucian uang perlu mendapatkan perlindungan dalam Sistem 
Peradilan Pidana Indonesia dan konsep ideal pemulihan aset bagi korban yang mengalami kerugian akibat tindak pidana pencucian uang.

\section{B. Metodologi}

Jenis penelitian yang penulis gunakan adalah penelitian hukum normatif atau bisa juga disebut penelitian hukum doktrinal. Menurut Terry Hutchinson sebagaimana dikutip Peter Mahmud Marzuki mendefinisikan bahwa penelitian hukum doktrinal yaitu : "doctrinal research: research wich provides a systematic exposition of the rules goverming a particular legal kategory, analyses the relationship between rules, explain areas of difficullty and, perhaps, predicts future development." (Penelitian doktrinal adalah penelitian yang memberikan penjelasan sistematis aturan yang mengatur suatu kategori hukum tertentu, menganalisis hubungan antara peraturan menjelaskan daerah kesulitan dan mungkin memprediksi pembangunan masa depan). (Peter Mahmud Marzuki, 2014 : 35).

\section{Hasil dan Pembahasan}

1. Perlindungan hukum pemulihan aset bagi korban dalam tindak pidana pencucian uang perlu dilindungi dalam Sistem Peradilan Pidana Indonesia

Sistem peradilan pidana adalah sistem pengendalian kejahatan yang terdiri dari lembaga - lembaga kepolisian, kejaksaan, pengadilan dan permasyarakatan terpidana (Mardjono Reksodiputro, 1993:1). Dikemukakan pula bahwa sistem peradilan pidana (criminal justice system) adalah sistem dalam suatu masyarakat untuk menanggulangi kejahatan (Romli Atmasasmita, 1996:15). Dalam mekanisme peradilan pidana, posisi korban sering kali tidak mendapatkan tempat yang adil, bahkan tidak bisa secara langsung ikut aktif berperan dalam sistem peradilan pidana karena kepentingannya sudah diserahkan kepada negara melalui Penuntut Umum dimana posisi korban setidaknya hanya sebagai alat bukti keterangan saksi. Posisi korban tindak pidana yang begitu penting dipelajari dalam suatu ilmu yaitu viktomologi.

Viktimologi adalah ilmu yang mempelajari tentang korban (victim $=$ korban) termasuk hubungan antara korban dan pelaku, serta interaksi antara korban dan sistem peradilan - yaitu, polisi, pengadilan, dan hubungan antara pihak-pihak yang terkait serta didalamnya juga menyangkut hubungan korban dengan kelompok-kelompok sosial lainnya dan institusi lain seperti media, kalangan bisnis, dan gerakan sosial (Andrew Karmen, 2017). Pengertian viktimologi, berasal dari bahasa latin victima yang berarti korban dan logos yang berarti ilmu. Secara terminologi, viktimologi berarti suatu studi yang mempelajari tentang korban, penyebab timbulnya korban dan akibat-akibat penimbulan korban yang merupakan masalah manusia sebagai suatu kenyataan sosial. Selain itu viktimologi juga mempelajari mengenai perlindungan yang harus diberikan oleh pemerintah terhadap masyarakat yang telah menjadi korban tindak pidana, tetapi disini viktimologi juga mempelajari peranan korban terhadap terjadinya tindak pidana khususnya tindak pidana pemerkosaan. Peranan korban yang dimasud itu seperti apa yang dilakukan oleh korban, dan dalam tindakan yang dilakukan oleh korban tersebut 
terdapat hubungan yang penting sehingga terjadinya tindak pidana (Dikdik M.Arief dan Elisatris Gultom, 2006:33-34)

Hukum pidana memperlakukan korban seperti hendak mengatakan bahwa satusatunya cara untuk melindungi korban adalah dengan memastikan bahwa si pelaku mendapatkan balasan yang setimpal. Padahal apabila kita hendak mengamati masalah kejahatan secara komprehensif, kita tidak boleh mengabaikan peranan korban dalam terjadinya kejahatan. Bahkan, apabila memperhatikan pada aspek pencarian kebenaran materiil sebagai tujuan yang akan dicapai dalam pemeriksaan suatu kejahatan, peranan korban pun sangat strategis, dengan demikian sedikit banyak menentukan dapat tidaknya pelaku kejahatan memperoleh hukuman yang setimpal dengan perbuatan yang dilakukanya. Dalam hubungannya antara pelaku kejahatan dengan korbannya, sistem hukum yang berlaku (KUHAP) sekarang kurang peduli terhadap kepentingan korban. Kehadiran korban dan saksi dalam proses peradilan selain tidak diberi kompensasi karena mereka meninggalkan pekerjaan dan membutuhkan biaya menuju ke tempat sidang, perlindungan keselamatan dari gangguan pelaku dan kelompoknya juga tidak dijamin. Kini dalam kehidupan praktis dunia hukum, yang sebelumnya tidak memberi tempat pada korban kejahatan dalam hukum, dengan perkembangan penelitian victimologi mulai mendapat perhatian (Muhamad Mustofa, 2013).

Menurut Lawrence M. Friedman, ada tiga unsur dalam sistem hukum, yaitu: (Lawrence M.Friedman, 2001:7-9). Pertama-tama, sistem hukum mempunyai struktur. Sistem hukum terus berubah, namun bagian-bagian sistem itu berubah dalam kecepatan yang berbeda, dan setiap bagian berubah tidak secepat bagian tertentu lainnya. Ada pola jangka panjang yang berkesinambungan - aspek sistem yang berada di sini kemarin (atau bahkan pada abad yang terakhir) akan berada di situ dalam jangka panjang. Inilah struktur sistem hukum - kerangka atau rangkanya, bagian yang tetap bertahan, bagian yang memberi semacam bentuk dan batasan terhadap keseluruhan. Struktur sistem hukum terdiri dari unsur berikut ini : jumlah dan ukuran pengadilan, yurisdiksinya (yaitu, jenis perkara yang diperiksa, dan bagaimana serta mengapa), dan cara naik banding dari satu pengadilan ke pengadilan lain. Jelasnya struktur adalah semacam sayatan sistem hukum- semacam foto diam yang menghentikan gerak. Aspek lain sistem hukum adalah substansinya. Yaitu aturan, norma, dan pola prilaku nyata manusia yang berada dalam sistem itu. Substansi juga berarti "produk" yang dihasilkan oleh orang yang berada dalam sistem hukum itu - keputusan yang mereka keluarkan, aturan baru yang mereka susun. Penekannya disini terletak pada hukum hukum yang hidup (Living law), bukan hanya pada aturan dalam kitab hukum (law books). Komponen ketiga dari sistem hukum adalah budaya hukum. Yaitu sikap manusia terhadap hukum dan sistem hukum - kepercayaan, nilai, pemikiran, serta harapannya. Dengan kata lain budaya hukum adalah suasana pikiran sosial dan kekuatan sosial yang menentukan bagaimana hukum digunakan, dihindari atau disalah gunakan. Tanpa budaya hukum, sistem hukum itu sendiri tidak akan berdaya - seperti ikan yang mati terkapar di keranjang, bukan seperti ikan hidup yang berenang di lautnya.

Dalam sistem hukum pidana, yakni sejak awal mula lahirnya hukum pidana, fokus subyek yang banyak disoroti adalah si pelaku, padahal dari suatu kejahatan, kerugian yang paling besar diderita adalah oleh si korban kejahatan tersebut. Dalam hal ini, sedikit sekali 
hukum ataupun peraturan perundang-undangan yang dapat kita temui yang mengatur mengenai korban serta perlindungan terhadapnya (Mardjono Reksodiputro, 1994:81). Bahwa hka-hak korban diambil alih oleh negara, korban sebagai pihak yang langsung dirugikan kepentingannya telah diwakili oleh Negara yang berperan sebagai pelaksana proses hukum dianggap tidak perlu lagi memiliki sejumlah hak yang memberikan perlindungan baginya dalam proses peradilan. (Weni Almoravid Dunga, 2009).

Tidak berlebihan apabila selama ini berkembang pendapat yang menyebutkan bahwa korban merupakan aset yang penting dalam upaya menghukum pelaku kejahatan. Pada sebagian kasus-kasus kejahatan, korban sekaligus merupakan saksi penting yang dimiliki untuk menghukum pelaku kejahatan. Sayangnya dalam kerangka pemeriksaan suatu perkara di mana korban merupakan saksi bagi pengungkapan suatu kejahatan hanya diposisikan sebagai instrument dalam rangka membantu aparat penegak hukum untuk menghukum si pelaku, dan tidak pernah berlanjut pada apa yang dapat negara serta aparat penegak hukum lakukan untuk si korban, sehingga penderitaan (kerugian) yang diderita korban dapat dipulihkan seperti keadan sebelum terjadi kejahatan yang menimpa dirinya (Dikdik M.Arief dan Elisatris Gultom, 2006:37).

Dalam perkembangannya tentang korban ini, telah dituangkan dalam Undang-undang nomor 13 Tahun 2006 tentang Perlindungan Saksi Dan Korban. Hal mana kepentingan korban di kuasakan pada suatu Lembaga yang di bentuk oleh undang-undang yakni Lembaga Perlindungan Saksi Dan Korban (LPSK). Kepentingan korban melalui LPSK tersebut tertuang dalam Pasal 7 Undang-Undang Nomor 13 tahun 2006 tentang Perlindungan Saksi dan Korban sebagai barikut :

1. Korban melalui LPSK berhak mengajukan ke pengadilan berupa :

a. hak atas kompensasi dalam kasus pelanggaran hak asasi manusia yang berat;

b. hak atas restitusi atau ganti kerugian yang menjadi tanggung jawab pelaku tindak pidana.

2. Keputusan mengenai kompensasi dan restitusi diberikan oleh pengadilan.

3. Ketentuan lebih lanjut mengenai pemberian kompensasi dan restitusi di atur dengan Peraturan Pemerintah.

Adapun dalam Peraturan Pemerintah Nomor 44 Tahun 2008 tentang Kompensasi, Restitusi, dan Bantuan Kepada Saksi dan Korban menyatakan menyatakan antara lain permohonan untuk memperoleh restitusi diajukan oleh korban, keluarga, atau kuasanya dengan surat kuasa khusus secara tertulis kepada pengadilan melalui LPSK. Pengajuan permohonan restitusi dapat dilakukan sebelum atau setelah pelaku dinyatakan bersalah berdasarkan putusan pengadilan yang telah memperoleh kekuatan hukum tetap dengan melampirkan bukti kerugian yang nyata-nyata diderita oleh korban atau keluarga yang dibuat atau disahkan oleh pejabat yang berwenang. Dalam hal permohonan Restitusi diajukan sebelum tuntutan dibacakan, LPSK menyampaikan permohonan tersebut beserta keputusan dan pertimbangannya kepada Penuntut Umum.

Sebagai bagian dari Sistem Peradilan Pidana maka Penuntut Umum menggunakan sarana KUHAP sebagai pelaksanaan penggabungan perkara, akan tetapi permohonan yang dimaksud tersebut maupun penggabungan perkara pokok dengan ganti kerugian pada prinsipnya pelaksanaannya menggunakan hukum perdata. 
Dalam Pasal 14c KUHP dinyatakan apabila hakim menjatuhkan pidana percobaan, maka hakim bersama-sama dengan syarat umum, hakim boleh mengadakan syarat khusus, bahwa orang yang dihukum itu akan menggantikan kerugian karena tindak pidananya, semua atau sebagian saja (Arif Gosita, 2009:117)

Sistem peradilan pidana di Indonesia yang terdiri dari sub sistem Kepolisian, Kejaksaan, Pengadilan, Rutan dan Lapas serta Advocat ternyata tidak memberikan ruang optimum bagi korban tindak pidana. Penyidik memiliki kekuasaan dalam melakukan penyidikan yang fokus pada fakta perbuatan perlaku, sedangkan Penuntut Umum adalah wakil kepentingan hukum sebagai wujud dari hukum publik demikian pula Pengadilan tidak ada ruang lebar bagi korban, bahkan korban sendiri sebenarnya hanya sebagai saksi yaitu orang yang mengalami sendiri kejadian, namun dalam proses peradilan pidana itu sendiri korban hampir tidak ada peranan baik dalam memutus berat ringannya pelaku sampai dengan restutusi yang tidak jelas pengaturannya dalam KUHAP tersebut sebab bukan merupakan bagian pidana pokok yang ditentukan dalam KUHP. Sehingga perlindungan hukum bagi korban tindak pidana untuk mendapatkan kembali haknya berupa kerugian ekonomi akibat tindak pidana yang terjadi.

Dalam hal ini Negara berkomitmen bahwa setiap warga negara harus di perlakukan baik dan adil sama kedudukannya di dalam hukum, juga dalam pengertian apakah ia seorang tersangka atau korban suatu tindak pidana, perikemanusiaan sebagai sendi nilai falsafah negara Pancasila menjiwai seluruh keberadaan hukum di negara Indonesia, mulai dari UUD 45 hingga kepada peraturan perundang-undangan ke bawahnya (Bambang Poernomo, 2001/2002).

Perlindungan hukum bagi masyarakat yang menjadi korban kejahatan serta mengalami kerugian ekonomi tentu tidak hanya dengan menyelesaikan kasus atau perkara tersebut ke persidangan melalui Sistem Peradilan Pidana di Indonesia sebagaimana diuraikan sebelumnya yang ternyata belum mengakomodir kepentingan korban itu sendiri. Namun negara seharusnya juga memberikan perlindungan bagi korban khususnya yang mengalami kerugian ekonomi akibat kejahatan yang terjadi, tentunya dengan memberikan pengaturan untuk memasukan hak-hak dari korban kejahatan tersebut dalam sistem peradilan pidana.

Menurut Fitzgerald, Teori perlindungan hukum Salmond bahwa hukum bertujuan mengintegrasikan dam mengkoordinasikan berbagai kepentingan dalam masyrakat karena dalam suatu lalulintas kepentingan, perlindunagn terhadap kepentingan tertentu dapat dilakukan dengan cara membatai berbagai kepentingan di lain pihak (Satijipto Raharjo, 2000:53). Kepentingan hukum adalah mengurusi hak dan kepentingan manusia, sehingga hukum memiliki otoritas tertinggi untuk menentukan kepentingan manusia yang perlu diatur dan dilindungi (Satijipto Raharjo, 2000:53). Perlindungan hukum harus melihat tahapan yakni perlindungan hukum lahir dari suatu ketentuan hukum dan segala peraturan hukum yang diberikan oleh masyarakat yang pada dasarnya merupakan kesepakatan masyarakat tersebut untuk mengatur hubungan prilaku antara angota-anggotamasyar masyarakat dan antara perseorangan dengan pemerintah yang dianggap mewakili kepentingan masyarakat. Dalam hal korban mengalami kerugian finansial berupa hilangnya uang atau barang akibat dari suatu kejahatan, maka salah satu perlindungan hukum bagi korban adalah upaya mengembalikan hak korban berupa 
uang atau barang yang sudah hilang tersebut akibat perbuatan agar dapat kembali kepada korban, inilah yang penulis maksud sebagai asset recovery (pemulihan aset). Asset recovey terhadap korban tersebut salah satu bagian penting untuk mencapai tujuan hukum yaitu keadilan khususnya bagi korban kejahatan yang belum memiliki posisi yang jelas dalam struktur sistem peradilan pidana. Korban kejahatan akan tetap merasa belum adil jika kerugian yang dideritanya akibat kejahatan dari pelaku tidak dapat dikembalikan dengan mekanisme peradilan pidana, sehingga hal ini jelas harus diwujudkan dalam sistem peradilan pidana di Indonesia.

Tindak Pidana Pencucian Uang sebagaimana diatur dalam Undang-Undang Nomor 8 Tahun 2010 tentang Pencegahan dan Pemberantasan Tindak Pidana Pencucian Uang sebenarnya merupakan pintu masuk bagi asset recovery, namun sayangnya undangundang tersebut terlalu minimalis, sebab lebih banyak membahas mengenai kriminalisasi suatu perbuatan dan alat kelengkapan untuk dapat digunakan untuk asset tracing (penelusuran aset), sedangkan mengenai asset hasil kejahatan yang dapat ditelusuri tersebut bagaimana cara pengembaliannya khususnya yang telah menjadi satu tercampur dengan kekayaan pelaku itu sendiri, belum diatur.

Tindak Pidana Pencucian Uang sebagaimana diatur dalam Undang-Undang No. 8 Tahun 2010, menunjukan adanya kriminalisasi perbuatan sebagaimana diatur dalam undang-undang tersebut, antara lain disebutkan pada Pasal 3 berupa menempatkan, mentransfer, mengalihkan, membelanjakan, membayarkan, menghibahkan, menitipkan, membawa ke luar negeri, mengubah bentuk, menukarkan dengan mata uang atau surat berharga atau perbuatan lain atas Harta Kekayaan yang diketahuinya atau patut diduganya merupakan hasil tindak pidana.

Kualifikasi perbuatan-perbuatan tersebut disusun sedemikian rupa untuk menjerat para pelaku tindak pidana pencucian uang, namun ada hal yang harus pula menjadi titik perhatian yaitu objek yaitu berupa harta kekayaan yang merupakan aset dari korban tindak pidana tersebut. Pasal-pasal dalam Undang-Undang No. 8 Tahun 2010 tersebut sudah mampu menjerat perbuatan para pelaku tindak pidana pencucian uang, namun hal tersebut ternyata tidak memberikan jaminan bagi korban untuk kembali mendapatkan asetnya yang telah hilang tersebut akibat perbuatan pelaku. Adapun dalam penjelasan umum Undang-Undang No. 8 Tahun 2010 tersebut antara lain dinyatakan bahwa dalam konsep antipencucian uang, pelaku dan hasil tindak pidana dapat diketahui melalui penelusuran untuk selanjutnya hasil tindak pidana tersebut dirampas untuk negara atau dikembalikan kepada yang berhak.

Atas penjelasan umum tersebut, jelas bahwa tujuan Undang-Undang Pencegahan dan Pemberatasan Tindak Pidana Pencucian Uang tersebut antara lain adalah penegakan hukum untuk menelusuri aset (harta kekayaan) dimana kemudian dikembalikan kepada yang berhak atau dirampas untuk negara. Namun ternyata substansi hukum dalam Undang-Undang tersebut belum menjangkau sampai dengan pengembalian aset kepada yang berhak atau dalam hal ini adalah korban tindak pidana. Pengembalian aset hasil tindak pidana sama sekali tidak diatur dalam Undang-Undang No. 8 Tahun 2010 tersebut, sehingga mengenai pengembalian hasil kejahatan berupa harta keyaaan tersebut jelas harus kembali kepada aturan pada KUHAP. 


\section{Konsep ideal pemulihan aset bagi korban yang mengalami kerugian akibat tindak pidana pencucian uang}

Tindakan penelusuran aset pribadi milik pelaku untuk disita adalah salah satu upaya pencegahan / preventif terjadinya tindak pidana pencucian uang pada saat penanganan predicate crime, namun tidak semua tindak pidana asal / tindak pidana pemicu terjadinya pencucian uang (predicate crime) sebagaimana yang diterangkan pada Pasal 2 ayat (1) UU PPTPU diberlakukan kegiatan penelusuran aset untuk dilakukan penyitaan (aset milik pribadi pelaku bukan barang hasil tindak kejahatan /corpora delictie) hanya tindak pidana yang menimbulkan kerugian keuangan negara, yakni : Korupsi. Pelaku Predicate Crime yang menghasilkan kekayaan / uang dalam jumlah besar dari tindak pidananya tersebut dapat dimungkinkan telah melakukan tindak pidana pencucian uang sebelum diketahui aparat penegak hukum sehingga seringkali aparat penegak hukum hanya melakukan sita terhadap barang yang diduga sebagai hasil kejahatan (corpora delictie) dan alat melakukan kejahatan (instrumenta delictie), terhadap aset yang didalilkan Pelaku Predicate Crime sebagai miliknya bukan hasil tindak pidana sudah untuk dilakukan penelusuran karena terbentur pada belum ada peraturan perundangundangan yang memberikan wewenang pada penegak hukum untuk melakukan upaya penelusuran aset untuk disita sebanyak 25 (dua puluh lima) tindak pidana asal Pencucian Uang (Predicate Crime) selain korupsi, maka upaya tersebut tidak dapat dilaksanakan. (Bambang Setyowahyudi, 2016:43-45)

Secara umum, konsep pengembalian barang bukti telah diatur dalam KUHAP yaitu pada Pasal 215 yang menyatakan bahwa "Pengembalian benda sitaan benda sitaan dilakukan tanpa syarat kepada yang paling berhak, segera setelah putusan dijatuhkan jika terpidana telah memenuhi isi amar putusan."

Adapun terkait dengan benda sitaan dalam Pasal 39 KUHAP dinyatakan bahwa yang dapat dikenakan penyitaan adalah :

a. Benda atau tagihan tersangka atau terdakwa yang seluruh atau sebagian diduga diperoleh dari tindakan pidana atau sebagai hasil dari tindak pidana;

b. Benda yang telah dipergunakan secara langsung untuk melakukan tindak pidana atau untuk mempersiapkannya;

c. Benda yang dipergunakan untuk menghalang-halangi penyidikan tindak pidana;

d. Benda yang khusus dibuat atau dipergunakan melakukan tindak pidana;

e. Benda lain yang mempunyai hubungan langsung dengan tindak pidana yang dilakukan.

Dalam Undang-Undang Nomor 8 Tahun 2010 tentang Pemberantasan Tindak Pidana Pencucian Uang yang mengatur mengenai penyitaan hanyalah satu pasal, yaitu Pasal 81 yang menyatakan bahwa dalam hal diperoleh bukti yang cukup bahwa masih ada Harta Kekayaan yang belum disita, hakim memerintahkan jaksa penuntut umum untuk melakukan penyitaan harta kekayaan tersebut.

Sebagaimana diuraikan di atas, pada umumnya penyitaan akan dikaitkan juga dengan perampasan apakah itu terkait dengan terbuktinya perkara dan harus diperintahkan perampasan oleh hakim atas harta benda yang disita untuk diserahkan pada yang berhak (dikembalikan kepada orang atau mereka yang disebut dalam putusan tersebut, kecuali 
jika benda tersebut menurut keputusan hakim dirampas untuk negara, untuk dimusnahkan atau untuk dirusakkan sampai tidak dapat dipergunakan lagi atau jika benda tersebut masih diperlukan sebagai barang bukti untuk perkara lain (Pasal 46 ayat (2) KUHAP), atau perampasan yang dikaitkan dengan pidana tambahan yaitu sebagaimana diatur pada Pasal 39 KUHP, yang dapat dirampas adalah : (Yenti Ganarsih, 2016:10).

a. Barang-barang kepunyaan terpidana yang diperoleh karena kejahatan;

b. Barang-barang kepunyaan terpidana yang dengan sengaja telah dipakai untuk melakukan kejahatan.

Terkait Pasal 39 huruf a, maka barang-barang tersebut adalah objek Tindak Pidana Pencucian Uang yang sejak awal penyidikan seharusnya sudah disita, karena hal ini menjadi focus Tindak Pidana Pencucian Uang, yaitu follow the proceed of crime (menelusuri hasil kejahatan). Jadi, putusan perampasan ini sangat tergantung pada profesionalisme penyidik, baik dalam hal penyitaan maupun dalam hal pemblokiran, meskipun bisa juga dikejar dengan Pasal 81 UU TPPU, seperti telah dijelaskan di atas, yaitu penyitaan yang dilakukan pada saat proses dipersidangan.

Namun konsep yang telah diatur sebagaimana diuraikan diatas masih sangat lemah jika dilihat dalam praktek, sebab hasil kejahatan apalagi berupa uang dan barang seringkali sudah tidak utuh namun sudah berubah dengan dicampur dengan harta sah dari pelaku itu sendiri. Salah satu contoh putusan pengadilan yang telah incracht adalah Putusan Pengadilan Negeri Bekasi No. 741/PID.B/2014/PN.Bks atas nama terdakwa FAJAR TRIANI Binti DARDIRI TS, yang terbukti melakukan tindak pidana Pasal 374 jo Pasal 64 ayat (1) KUHP dan Kedua Pasal 3 UU RI No. 8 Tahun 2010 tentang Pemberantasan Tindak Pidana Pencucian Uang jo Pasal 64 ayat (1) KUHP, dimana terdakwa tersebut menggelapkan uang korban Rumas Sakit Mitra Keluarga Bekasi Barat sebesar Rp. 16.340.984.463,-. Sejak 2009 sampai dengan 2013, kemudian uang tersebut terdakwa membelanjakan uang tersebut untuk kebutuhan hidup terdakwa dan keluarga dan juga membeli kendaraan yaitu Honda Jazz, Mitsubushi Pajero, Mobil Honda CRV dan membeli rumah dan merenovasi rumah. Terdakwa juga membeli tas-tas, sepatu dan baju mewah sert HP, berlibur ke Lombok, Bali, Solo dan Jogja. Adapun barang bukti tersebut diserahkan kepada korban yaitu Rumah Sakit Mitra Keluarga Bekasi, sedangkan lainnya adalah untuk merenovasi rumah terdakwa sebesar Rp. 500.000.000,- sedangkan harga rumah milik terdakwa yang sah hanya sebesar Rp. 250.000.000,- menunjukan bahwa hukum pidana kita serta sistem peradilan pidananya belum bisa menjangkau pada area asset recovery tersebut, padahal jika predicate offence-nya adalah korupsi maka rumah tersebut pasti disita dan dilelang untuk menggantikan kerugian keuangan negara akibat perbuatan terdakwa, namun karena predicate offence adalah penggelapan maka tentu tidak ada solusi secara pidana jika terntata asset korban kejahatan telah tercampur dengan aset sah pelaku.

Hal ini berbeda jika predicate offence adalah tindak pidana korupsi, maka dapat diberlakukan pidana tambahan berupa uang pengganti sebagaimana Pasal 18 UndangUndang RI Nomor 31 Tahun 1999 jo Undang-Undang RI Nomor 20 Tahun 2001 tentang Pemberantasan Tindak Pidana Korupsi, yaitu dengan disita kemudian dilelang, maka kerugian negara dikembalikan / dipulihkan sedangkan sisanya tentunya dikembalikan kepada pelaku karena merupakan uang / aset sah dari pelaku. Sedangkan, jika predicate 
offence adalah penggelapan sebagaimana diatas, maka penyelesaian pemulihan asetnya menjadi lebih rumit. Bahkan tidak jarang justru tidak bisa diselesaikan, hingga kemudian korban menempuh jalur perdata dengan melakukan gugatan perdata perbuatan melawan hukum 1365 KUHPerdata atau melalui LPSK, ini menunjukan hukum pidana kita masih belum mampu secara efektif dan efisien menjamin keadilan bagi korban tindak pidana. Terlihat jelas perlakuan yang berbeda terhadap korban yang merupakan negara dan korban yang merupakan orang. Sebab substansi hukum dalam tindak pidana pencucian uang tersebut tidak menjamin pengembalian kerugian korban kejahatan asal, tidak heran jika hakekat follow the money hanya sebatas pada kriminaliasi dan pembantuan pengungkapan predicate offence meskipun melibatkan struktur hukum baru pencukung yaitu Pusat Pelaporan Analisis Transaksi Keuangan (PPATK) (Indonesian Financial Transaction Reports And Analysis Centre).

Konsep yang ideal sebenarnya sudah ada dalam Undang-Undang No. 31 Tahun 1999 jo Undang-Undang No. 20 Tahun 2001 tentang Pemberantasan Tindak Pidana Korupsi dalam menghadapi persoalan tersebut yaitu dengan dengan ketentuan Pasal 18 Undang-Undang No. 31 Tahun 1999 jo Undang-Undang No. 20 Tahun 2001 tentang uang pengganti dan perampasan dan penyitaan aset pelaku maka dalam kasus penggelapan dalan jabatan sebagaimana diuraikan di atas tersebut rumah hasil beli dan renovasi tersebut dapat disita dan kemudian dilelang, sedangkan hasil lelang tersebut sesuai kerugian yang dialami negara dan diperoleh terdakwa maka dikembalikan kepada negara sebagai pengganti kerugian keuangan negara (uang pengganti), sedangkan sisanya tentu jika itu uang / asset sah terdakwa akan dikembalikan kepada terdakwa. Kosep asset recovery seperti itu ternyata hanya ada di perkara tindak pidana pidana korupsi, sedangkan terhadap perkara lain sebagai tindak pidana asal tidak ada konsep seperti itu sehingga untuk memulihkan asset korban mengalami kesulitan karena kurangnya substansi hukum yang ada saat ini dalam Sistem Peradilan Pidana.

Adapun ketentuan Pasal 18 ayat (1) dan (2) Undang-Undang No. 31 Tahun 1999 jo Undang-Undang No. 20 Tahun 2001 tentang Pemberantasan Tindak Pidana Korupsi :

1. Selain pidana tambahan sebagaimana dimaksud dalam Kitab Undang-undang Hukum Pidana, sebagai pidana tambahan adalah:

a. perampasan barang bergerak yang berwujud atau yang tidak berwujud atau barang tidak bergerak yang digunakan untuk atau yang diperoleh dari tindak pidana korupsi, termasuk perusahaan milik terpidana di mana tindak pidana korupsi dilakukan, begitu pula dari barang yang mengantikan barang-barang tersebut;

b. pembayaran uang pengganti yang jumlahnya sebanyak-banyaknya sama dengan harta benda yang diperoleh dari tindak pidana korupsi.

c. penutupan Seluruh atau sebagian perusahaan untuk waktu paling lama 1 (satu) tahun;

d. pencabutan Seluruh atau sebagian hak-hak tertentu atau penghapusan Seluruh atau sebagian keuntungan tertentu, yang telah atau dapat diberikan oleh Pemerintah kepada terpidana.

2. Jika terpidana tidak membayar uang pengganti sebagaimana dimaksud dalam ayat (1) huruf b paling lama dalam waktu 1 (satu) bulan sesudah putusan pengadilan yang telah memperoleh kekuatan hukum tetap, maka harta bendanya dapat disita oleh jaksa dan dilelang untuk menutupi uang pengganti tersebut. 
Hubungan antara tindak pidana korupsi dan tindak pidana pencucian uang sangat erat kaitannya. Tindak pidana korupsi merupakan salah satu tindak pidana asal (predicate crime) dari tindak pidana pencucian uang sebagaimana diatur dalam Pasal 2 ayat (1) Undang-Undang Nomor 8 Tahun 2010 tentang Pencegahan dan Pemberantasan Tindak Pidana Pencucian Uang. Pencucian uang merupakan sarana bagi para pelaku tindak pidana korupsi untuk melegalkan uang hasil korupsinya dengan cara menyembunyikan ataupun menyamarkan asal-usul uang yang diperoleh dari hasil tindak pidana korupsi melalui mekanisme sistem keuangan (financial system) (Malto S. Datuan dkk, 2017).

Negara seharusnya mampu memberikan keadilan yang sama bagi korban sebagaimana pada saat negara sebagai korban tindak pidana korupsi, sebab model asset recovery tersebut dalam tindak pidana korupsi lebih efektif memulihkan aset negara sehingga dapat diterapkan untuk tindak pidana umum dengan tindak lanjut tindak pidana pencucian uang. Oleh karena itu, konsep Pasal 18 Undang-Undang Pemberantasan Tindak Pidana Korupsi yang merupakan pidana tambahan seharusnya masuk dalam ketentuan UndangUndang Pemberantasan Tindak Pidana Pencucian Uang. Konsep restitusi pengembalian kerugian korban kejahatan dari pelaku seharusnya dikonsep dengan mekanisme yang paling mendekati dengan ketentuan pada Undang-Undang Pemberantasan Tindak Pidana Korupsi, hanya saja pidana pengganti penjara bagi terdakwa yang tidak mampu sebaiknya tidak diterapkan dalam tindak pidana asal berupa tindak pidana umum. Sehingga jika terdakwa tidak mampu maka ketentuan gugat ganti rugi yang diatur secara perdata tetap dapat dijalankan.

\section{Simpulan}

1. Sebagai negara hukum, negara wajib memberikan perlindungan terhadap warga negaranya termasuk dalam hal sebagai korban tindak kejahatan yang mengalami kerugian. Oleh karena itu, undang-undang pemberantasan tindak pidana pencucian uang bisa dijadikan alat untuk asset tracing (penelusuran aset) dengan perangkat struktur hukum yang ada, namun dalam undang-undang tersebut belum menjangkau mengenai bagaimana pengembalian aset korban kejahatan yang mengalami kerugian khususnya aset korban tersebut telah menjadi satu dengan aset sah pelaku. Disinilah pentinya negara dalam memberikan perlindungan kepada korban kejahatan, sehingga korban kejahatan memiliki posisi dalam sistem peradilan pidana di Indonesia demi tercapainya rasa keadilan bagi masyarakat pada umumnya dan korban kejahatan pada khususnya.

2. Konsep ideal asset recovery baru ada di dalam undang-undang pemberantasan tindak pidana korupsi, dimana konsep uang pengganti masuk dalam pidana tambahan yang dibebankan kepada terdakwa sehingga korban yaitu negara yang mengalami kerugian keuangan dapat dikembalikan kerugian tersebut. Konsep uang pengganti ini yang bisa menjadi solusi dalam memasukan posisi korban dalam sistem peradilan pidana Indonesia. Sehingga tindak pidana asal apapun selama dilakukan penyelesaian perkaranya dengan pencucian uang maka meskipun aset hasil kejahatan milik korban telah tercampur dengan aset pelaku maka dengan konsep uang pengganti aset tersebut dapat dilelang dan kemudian digunakan untuk menggantikan kerugian korban, sedangkan pelaksanaannya tetap dilakukan oleh Jaksa sebagai pelaksana putusan pengadilan. 


\section{E. Saran}

Kepada lembaga legislatif agar melakukan revisi terhadap Undang-Undang No. 8 Tahun 2010 tentang Pemberantasan Tindak Pidana Pencucian Uang dengan memasukan konsep asset recovery khususnya yang terhadap aset korban kejahatan yang telah menyatu dengan asset pelaku dengan cara penambahan pidana uang pengganti, namun jika tidak membayar dalam waktu tertentu akan dilelang harta kekayaan pelaku tersebut dan kemudian dikembalikan kepada korban tindak pidana sebesar harta bendanya yang dirugikan oleh pelaku sebagaimana konsep asset recovery pada undang-undang peberantasan tindak pidana korupsi.

\section{F. Daftar Pustaka}

\section{Buku}

Romli Atmasasmita. 1996. Sistem Peradilan Pidana (Criminal Justice System) Perspektif Eksistensialisme dan Abolisionalisme. Jakarta: Penerbit Bina Cipta.

Yenti Ganarsih. 2016. Penegakan Hukum Anti Pencucian Uang dan Permasalahannya di Indonesia. Ctk. Kedua. Jakarta: PT. Raja Grafindo Persada.

Arif Gosita. 2009. Masalah Korban Kejahatan : kumpulan karangan/Arif Gosita, Jakarta: Universitas Trisaksi.

Evi Hartanti. 2007. Tindak Pidana Korupsi. Jakarta: Sinar Grafika.

Peter Mahmud Marzuki. 2014. Penelitian Hukum Edisi Revisi. Jakarta: Kencana Prenada Media Group.

M. Arief, Dikdik dan Elisatris Gultom. 2006. Urgensi Perlindungan Korban Kejahatan, Antara Norma dan Realita. Jakarta: PT Raja Grafindo Utama.

Lawrence M.Friedman. 2001. American Law An Introduction Second Edition (Hukum Amerika Sebuah Pengantar) Penerjemah Wishnu Basuki. Jakarta: PT. Tatanusa.

Bambang Poernomo. 2001. Hukum Dan Viktimologi. Bandung: Bahan kuliah pada Program Pascasarjana Ilmu Hukum Pidana Universitas Padjadjaran Bandung.

Reksodiputro. 1994. Mardjono. Kriminologi dan Sistem Peradilan Pidana. Jakarta: LKUI.

Satjipto Raharjo. 2000. Ilmu Hukum. Bandung : PT. Citra Aditya Bakti.

Mardjono Reksodiputro. 1993. Sistem Peradilan Pidana Indonesia (Melihat Kepada Kejahatan Dan Penegakan Hukum Dalam Batas Batas Toleransi). Jakarta : Fakultas Hukum Unversitas Indonesia.

Bambang Setyowahyudi. 2016. Strategi Penanganan Tindak Pidana Pencucian Uang. Surakarta: UNS Press. 


\section{Peraturan}

Kitab Undang-Undang Hukum Pidana

Kitab Undang-Undang Hukum Acara Pidana

Kitab Undang-Undang Hukum Perdata

Undang-Undang No. 8 Tahun 2010 tentang Pemberantasan Tindak Pidana Pencucian Uang

Undang-Undang No. 31 Tahun 1999 tentang Pemberantasan Tindak Pidana Korupsi

Undang-Undang No. 20 Tahun 2001 tentang Perubahan dan Penambahan atas Undang-Undang No. 31 Tahun 1999 tentang Pemberantasan Tindak Pidana Korupsi

Peraturan Jaksa Agung RI Nomor : PER-013/A/JA/06/2014 tentang Pemulihan Aset

\section{Jurnal}

Malto S. Datuan, "Bismar Nasution. 2017. Asset Recovery Dalam Tindak Pidana Korupsi Melalui Instrumen, Undang-Undang Tindak Pidana Pencucian Uang”. USU Law Journal, Vol.5.No.2.

Muhammad Mustofa. 2013. "Kehadiran Negara dalam Perlindungan Saksi dan Korban Kejahatan”. Jurnal Perlindungan. Edisi 3. Vol.1.

Weny Almoravid Dunga. 2009. "Implementasi Undang-Undang Perlindungan Saksi dan Korban di Gorontalo". Mimbar Hukum. Vol. 21. No. 2.

\section{Internet}

https://www.kejaksaan.go.id/pusdiklat/

https://id.wikipedia.org/wiki/Viktimologi.

http://putusan.mahkamahagung.go.id/putusan/c9da5ee77817b8ac21fc522644c72b98 